\title{
Inter-Religious Dialog Now and Then in West Java
}

\author{
TIMOTIUS SUKARNA \\ Sekolah Tinggi Teologi Kadesi Bogor, Indonesia \\ David Ming \\ Sekolah Tinggi Teologi Kadesi Bogor, Indonesia \\ Djuniasih \\ Sekolah Tinggi Teologi Kadesi Bogor, Indonesia \\ Maria Titik Windarwati \\ Sekolah Tinggi Teologi Kadesi Bogor, Indonesia
}

\begin{abstract}
Religious tolerance is a philosophy that is expected to be manifested in religious life in the Republic of Indonesia which is based on Pancasila. All religions in Indonesia, both those with majority and minority followers, have agreed to uphold the noble values contained in Pancasila. In addition, the government has also provided relatively clear boundaries, there is freedom, but there are still boundaries and must respect each other. Pancasila, the Constitution, UU, PP, Kepres and all regulations that apply in this country, must be upheld by every religious adherent in this country. The government guarantees the freedom to embrace one religion and practice it according to its beliefs. But it seems that in the concept of government, all Indonesian citizens are already religious, because it is based on the first precepts in Pancasila, namely: That the Unitary State of the Republic of Indonesia is based on the One God " This study considers the potential of the first sila of Pancasila as a healthy interculturality by virtue of its open concept of divinity, namely "cultured divinity". The finding is that the first sila of Pancasila can be defined as an open and active intercultural hermeneutics. The fluidic, accommodative, and open nature of the first sila of Pancasila, makin it possible to values contributed from anywhere, is the advantage of Pancasila that makes it acceptable to anyone living in Indonesia
\end{abstract}

Keywords: Pancasila, inter-Religious, overlapping identity

DOI: $10.7176 / \mathrm{JLPG} / 111-04$

Publication date:July $31^{\text {st }} 2021$

\section{INTRODUCTION}

It is not a coincidence that Christians in Indonesia live in the midst of a non-Christian majority spread across various islands and archipelago in the country. From God's side, nothing happens by chance, God has a plan, so that every believer can carry out his duties as a witness, as light or salt, capable of enlightening or salting this nation as God wills. Since 1957, a belief system cannot be categorized as a religion, and at that time people who originally adhered to tribal beliefs or religions were urged to include one of the religions recognized by the state. So thus there was a kind of government intervention to people who had not followed one religion at that time, to immediately choose one religion and include it on their KTPs, so it is not wrong to say that the government has "put religion" on the people. The religion that was listed on their KTP at that time, was not their choice of heart, but it turned out that it was very difficult to change or give up again, when they already had a choice of their own heart. That is why it is only natural that in the future there will be religious syncritism, even today. On their KTPs they state one religion, but in their daily life they still practice other beliefs; this phenomenon by Dr. Baker and by Dr. Harun Hadiwiyono ${ }^{1}$ it is called a "fluidic", meaning that beliefs, tribal religions, even like Hinduism and Buddhism, have become "fluidic" in certain religions, especially Islam. Can it be said that they have embraced one religion. If it doesn't mean they should be given the freedom to choose and embrace one religion according to their own conscience, or return to their ancestral beliefs? If that happens, it means that all legal religions in this country have the opportunity to witness or preach to the group.

But the question is how a believer on the one hand can carry out his duties as a believer, but on the other hand he can still coexist with other people in a very heterogeneous society, coupled with the existence of laws, and various government regulations, of The government, fatwas from the regional MUI (Majelis Ulama Indonesia) and regional regulations in each region which greatly limit the movement of believers in carrying out their duties in the Evangelisation. On the one hand it is part of the believers, but on the other hand it is part of this very pluralistic Indonesian society, which has an obligation to maintain order, harmony and stability of the nation, as well as an obligation to respect and respect the adherents of each other. other religions that are legal and protected by the 1945 Constitution.

\footnotetext{
${ }^{1}$ Hidayat Nurwahid, Ensiklopedi Islam untuk Pelajar Indonesia, 2002
} 
The struggle from time to time is how Christians in Indonesia can carry out their duties, without having to clash and violate all existing regulations in this country, and how Christians can co-exist with followers of other religions.

\section{METHOD OF RESEARCH}

This study uses qualitative methods with literature review approaches, analysis studies, observations, surveys and interviews.

\section{DISCUSSION AND RESULT}

\section{History of the entry of Islam in Indonesia}

The Sundanese claim that: "Islam is Sundanese, Sundanese is Islam", "the Sundanese were originally Islam", "Islam is the native religion of the Sundanese people"; It is as if Sundanese people must always be Muslim, because before they were born they were already Muslims.

Islam is actually the same as Christianity, which is a religion that originates from outside, only it may have entered Indonesia relatively earlier than Christianity. Some Islamic figures feel that Islam has entered Indonesia in the seventh century because it is thought that in $674 \mathrm{AD}$ Arab traders had started to settle on the west coast of Sumatra. ${ }^{1}$ But the author feels that there is no solid fact that states that they are Muslims. Because around the seventh century Arabia was not completely Islamized by Muhammad and his followers.

The time span of the entry of Islam to Indonesia with the entry of Christianity is not really that much different, because some travelers have found several inscriptions in public cemeteries in Sumatra, and from the inscriptions it is thought that Christianity entered Sumatra before the thirteenth century. Because Islam entered Indonesia around the century eleven (XI). And at the end of the thirteenth century, the Islamic Kingdom was established in the archipelago, the first being the Sultanate of Samudra Pasai in Aceh, which is located in North Aceh, to be precise in Lhokseumawe, namely in $1297 .{ }^{2}$ When viewed from the point of view of time, Hinduism and Buddhism actually entered Indonesia much earlier than Islam. The way Islam entered Indonesia has been studied in public schools, starting from Elementary School (SD) to Senior High School (SLTA). Islam entered the archipelago, namely through traders from Arabia (especially Hadramaut), Persia, Gujarat in West India whose main purpose was to come to various islands in the archipelago to trade, namely in the eleventh century (XI). These traders came to various coastal cities of the archipelago, such as Aceh, Demak, Cirebon, Gresik and other coastal cities. But it turns out that in the end when they already have good relations with the rulers or kings of the region, they also begin to carry out religious announcements to these rulers, and history records that not a few of these rulers eventually embraced Islam, and after the kings or the rulers embraced Islam, and then these rulers advised and obliged their people to embrace Islam as well, so then Islamic-based kingdoms were established, especially those in the coastal areas.

\section{Development of Islam in Indonesia}

In its development in Indonesia, Islam has at least three phases or stages, namely: the "as a newcomer" phase, the "struggle" phase to gain identity and followers; and third is the "ruler" phase, namely the phase when Islam has become a religion with a large number of followers, so that in many ways "he" seems to be a ruler.

Islam in a Phase As a "Newcomer"

Islam in the phase as a newcomer, in the archipelago at that time did not show much difference from other religions in that phase. In fact, it seems that Islam can adapt more in various aspects, be it social aspects, economic aspects, culture, and even Islam can adapt to religions that came earlier or entered earlier, including Hinduism and Buddhism. As a "newcomer" Islam hardly shows a confrontational attitude, this is very different from Islam when it has become the majority religion.

The soft attitude or compromise of Islam above was one of the factors that caused Islam to be accepted more quickly and easily in various coastal cities at that time. An attitude of compromise with tribal culture and religion, animism and dynamism, coupled with an attitude of compromise with Hinduism and Buddhism, which were the religions of the rulers and many of their followers at that time, has brought

Islam to the form it is today. For example, on the island of Java, especially around Central Java and the Special Region of Yogyakarta, we will find Muslims or adherents of the Islamic religion who are dubbed by the term "Islam Abangan" or "Islam Kejawen". The meaning of the nickname Islam Abangan or Islam Kejawen is inherent in such a way in the daily lives of the average people of Central Java, Yogyakarta Special Region, and even people of East Java. This can be seen in various practices of daily life and also in various rituals, including a Muslim who is devout in practicing his religion, but when he is sick or one of his family members is sick, then he goes to a shaman or "smart person" to ask for medicine or healing from the shaman, then he is given plain

\footnotetext{
${ }^{1}$ Sukarna, Diktat Sosiologi (Manusia dan Kebudayaan di Indonesia), STT Kadesi.

${ }^{2}$ Iwan Gayo, Buku Pintar, seri Junior, Jakarta : Upaya Warga Negara.. 2003. p.86-87
} 
water or incantations to treat the pain and then he performs various "shari'a" or provisions that have been outlined by the shaman, including providing seven kinds of flowers, frankincense, smooth black chicken, and so on. etc. When paying attention to such matters, it is obvious that apart from the person concerned embracing Islam, in fact the person is also practicing part of the Shari'a of another belief or religion, namely Hinduism. And if then the shaman says that some of the conditions must be brought and placed under a large, very shady banyan tree outside the village near a spring, then it is clear that this person is also practicing the belief in Hinduism, he is also practicing. rituals of Animism and Dynamism. In fact, most Indonesians practice such living practices, regardless of their ethnicity, especially those who still live in villages or regions. In connection with the rituals and practices of life on Dr. Bakker, and also Dr. Harun Hadiwiyono calls him a "stowaway" meaning Hinduism, Buddhism, animism, dynamism, and various faiths in Indonesia are stowaways from certain religions, especially Islam. His dress is Islamic, the identity card (KTP) is written with Islam, but practices from other faiths are still clearly tucked away. ${ }^{1}$

In fact, such practices are evident in the daily lives of the Sundanese people in West Java, as well as in other ethnic groups in Indonesia. The life practice of Muslims is like this because of the initial "mistakes" of the broadcasters, as well as the government or rulers in the past, who had "put on religious clothes" to some Indonesian people.

But in addition to the factors that have been described above, many experts also believe that the practice of going on the pilgrimage is an adoption of Islam to the old religion in the Middle East, namely the religion or belief of the ancient Arabs which they often call the religion of the "era of ignorance. Or the dark ages. But the beliefs or ritual practices they adopted were then given new content and nuances, so that it became like the practice of going on the pilgrimage as it is known to the public today. ${ }^{2}$ But apart from the nature of Islam that can compromise other beliefs, the author also sees other factors, including that Islam was once a religion of "newcomers" in the Republic of Indonesia. As a newcomer, he must be able to adapt to existing beliefs or religions in the area so that his existence as a new religion can be accepted easily, so as to win as many followers as possible.

\section{Islam in the "Struggle" Phase}

In this phase, namely after Islam passed the phase of being a newcomer to the archipelago, Islam entered the "struggle" phase, namely the phase of struggling to get as many followers as it is today. ${ }^{3}$ Islam is a missionary religion, meaning that Islam is a dynamic religion, which continues to move forward to get as many followers as possible in various ways, or in other words Islam is an aggressive religion, in this case it is almost the same as Christianity. Islam has made various efforts, including the first one is: Syiar. Adherents of Islam in new areas, on average, are equipped for this task, apart from being educated in religious matters, so that they have a solid faith in Islam, they are also educated so that they can carry out religious propagation, among others through preaching. A Muslim has an obligation to be able to read the Koran, apart from being able to perform the obligatory prayers for five times, that is why Islamic leaders are very active in advising, encouraging followers to attend recitations, not even a few Islamic scholars who set up study associations. AlQuran, where one of the materials is reading the Koran and also preaching. People who enter the Islamic religious study association at this time are better known as "pondok" and the people or students are known as "santri", and these students will later depart or return to their respective hometowns. each to carry out religious announcements in their hometown or in a new place. ${ }^{4}$

Second, Islam in Indonesia has also experienced tremendous growth due to the intervention of the rulers at that time. The broadcasters, both local and immigrant, who were mostly wealthy merchants from India and the Middle East, had a very effective focus at that time, namely focusing on the rulers or kings of the region, or officials. important or high officials in a kingdom. History records that many kings or sunan embraced Islam, and later on with the power or authority they had they propagated their new religion. Very solid evidence is that from the nine guardians known as Wali Songo, all of them have the title of sunan, including Sunan Kalijogo, Sunan Ampel, Sunan Bonang, Sunan Kudus, Sunan Gresik, Sunan Giri, Sunan Muria, Sunan Drajat, Sunan Gunung Jati. $^{5}$ Some of them were rulers in the kingdom or in their respective areas at that time, scientists or people who were highly knowledgeable and had extraordinary powers, so they became very influential people, they were also great scholars. and they are people who are very active in the spread of Islam, and it can be said that Wali Songo is the main figures who have a very big role in the spread of Islam in this archipelago, especially the island of Java, for example Sunan Gunung Jati, one of the Wali Songo. which was very instrumental in the spread of Islam in West Java, especially Cirebon. He is also the founder of the Banten Sultanate dynasty which

\footnotetext{
${ }^{1}$ Robert Morey, Islamic Invasion, “Confronting the World’s Fastest Growing Religion” Las Vegas: Christian Scholars Press. 1992, p.34

${ }^{2}$ Ibid

${ }^{3}$ Darmaputera, Eka. 1992. Pancasila, Identitas dan Modernitas: Tinjauan Etis dan Budaya, Jakarta : BPK Gunung Mulia,p.10

${ }^{4}$ Ibid

${ }^{5}$ De Jong, Kees. 2008. “Keanekaragaman Bentuk Kekristenan Global”, Gema Teologi, Vol. 32, No. 1, April 2008.
} 
began with his son, Sultan Maulana Hassanudin. On the initiative of Sunan Gunung Jati, an attack on Sunda Kelapa was carried out in 1527, under the leadership of Fatahilah, the warlord of the Demak Sultanate who was also the son-in-law of Sunan Gunung Jati. ${ }^{1}$

Sunan Ampel. Sunan Ampel started his preaching from an Islamic boarding school which was founded in Ampel Denta (near Surabaya). Because of that he is known as the coach of the first Islamic boarding school in East Java. Sunan Giri, Raden Broken, Sunan Bonang and Sunan Drajat were students of Sunan Ampel. ${ }^{2}$

Sunan Gresik. Besides being known as Maulana Malik Ibrahim, Sunan Gresik is also known as Maulana Magribi (Sheikh Magribi) because he is thought to have come from the Magribi region (North Africa). However, until now the history of the place and year of his birth is not known with certainty. He is thought to have been born around the middle of the 14th century. He comes from a devout Muslim family and studied Islam since he was a child, but it is not known who his teacher was, until he later became a scholar. ${ }^{3}$

Sunan Bonang spread Islam by adjusting to the cultural styles of the Javanese people who like wayang and gamelan music. For that he created repertoire that has Islamic values. Each verse of the song is interspersed with two sentences of syahadat (syahadatain) ${ }^{4}$ so that the accompanying gamelan music is now known as sekaten. Sunan Giri whose real name is Raden Paku is the son of Maulana Ishak. He was assigned by Sunan Ampel to broadcast Islam in Blambangan. Sunan Giri studied at the Ampel Denta Islamic Boarding School. As an adult, on a pilgrimage trip with Sunan Bonang, he stopped at Pasai to deepen his religious knowledge. Upon his return to Java, Sunan Giri founded a pesantren in the Giri area. He also sent many preachers to Bawean (Madura), even to Lombok, Ternate, and Tidore in Maluku. ${ }^{5}$

Sunan Drajat was known as a saint with a high social spirit. He gave a lot of help to orphans, the poor, the sick and the miserable. His great concern for social problems was very appropriate at that time, because he lived when the Majapahit Empire collapsed (around 1478) and the people experienced an atmosphere of crisis and concern. ${ }^{6}$ Sunan Muria was one of the Wali Songo who contributed greatly to the spread of Islam in rural areas. This son of Sunan Kalijaga is known to be alone and lives in the village with ordinary people. In broadcasting Islam, Sunan Muria always made remote villages his operations. ${ }^{7}$

Sunan Kudus or Jafar Sadiq was called wali-al-ilmi (knowledgeable person) by the Wali Songo because he had special expertise in the field of religion. Because of his expertise, he was visited by many knowledge claimants from various regions. He is also trusted to control the government in the Kudus area. Hence, he became the religious leader as well as the government leader in the region ${ }^{8}$

Sunan Kalijaga is also known as a cultural observer and artist (sound art, carving and clothing). He created a variety of wayang stories that breathe Islam. Sunan Kalijaga also introduced a form of wayang made from goat skin (wayang kulit), because at that time the popular wayang was painted on a kind of wide paper (wayang beber). In the art of sound, he is the songwriter of Dandanggula. ${ }^{9}$

\section{Islam in Phase as the Religion of the Majority}

The persistence of the guardians or Wali Songo, Islamic scholars, students, and also with the intervention of the rulers who had embraced Islam at that time made Islam in a not too long time, has become a widely recognized religion throughout the city and region. coast, even reaching cities or kingdoms that are far from the coast, even through attacks or wars carried out by kingdoms on the coast that have embraced Islam, has made Islam the religion.

After Islam became big and the majority religion, it was clear that its attitude was different from Islam, when it was still in a position as a minority religion, or a newcomer who still had a small number of followers. After becoming the majority of Islam it became the ruling religion, and even influenced the rulers, government and the running of government, even the Dutch colonialism government for nearly three and a half centuries in this archipelago. The attitude of the Dutch government was very careful, because they did not want to come into contact with Islam, which was already one of the majority religions at that time, because if this contact happened

\footnotetext{
${ }^{1}$ Iwan,. Buku Pintar seri Junior, p 107.

2 Ibid

${ }^{3}$ Adeney-Risakotta, Bernard. 1997. “Allah yang Bhineka Tunggal Ika”, Duta Wacana: Majalah Ilmiah Universitas Kristen Duta Wacana, I/2, Oktober 1997,p.7

${ }^{4}$ Ibid

${ }^{5}$ Adeney-Risakotta, Bernard 2015. "Imajinari Sosial Indonesia dan Barat", dalam Bernard Adeney- Risakotta (ed.), Mengelola Keragaman di Indonesia: Agama dan Isu-isu Globalisasi, Kekerasan, Gender

dan Bencana di Indonesia, Yogyakarta: ICRS-Yogyakarta dan Mizan,p.8

${ }^{6} \mathrm{Ibid}$

${ }^{7}$ Adian, Donny Gahral. 2017. "Radikalisme dan Pancasila", Kompas, 14 Januari 2017.

${ }^{8}$ De Wit, Hans. 2004. "Intercultural Bible Reading and Hermeneutics", dalam Hans de Wit (ed.), Through the Eyes of Another: Intercultural Reading of the Bible, Amsterdam: Institute of Mennonite Studies dan Vrije Universiteit,p.45

${ }^{9}$ Dewan Karya Pastoral Keuskupan Agung Semarang. 2016. Nota Pastoral Arah Dasar KAS 2016- 2020: Membangun Gereja yang Inklusif, Inovatif dan Transformatif demi Terwujudnya Peradaban Kasih di Indonesia, Semarang: Dewan Karya Pastoral Keuskupan Agung Semarang.
} 
it would clearly be very troublesome for the Dutch government, and it would inevitably lead to a wave of resistance and rebellion. The Dutch government at that time did not expect this to happen, because if the resistance from Muslims or Islamic-based coastal kingdoms would disrupt their "business" in the region. The prudential attitude of the Dutch government has made the Dutch government, especially the Governor-General who is the ruler of the Archipelago or Indonesia today, to appear to have shown his siding with Islam compared to his siding with Christianity which in fact is the religion brought by Dutch zending-zending to ancient time. This was very clearly the case with the churches at that time, namely that it was often difficult to obtain legality or permission from the Dutch East Indies government at that time, even to get permission to preach the gospel in certain areas had to take care of permits to the Queen or King in the Netherlands. . And what happened to Pinkster Beweging, which later became the Pentecostal Movement Church or GGP, through its founder, namely Rev. Dr. John Thissen, at that time to get permission to preach the gospel to a new area, namely from the Priangan area or Bandung, now it extends to the Batavia area, namely Jakarta Now, namely in 1923, he had to take care of permits directly to the Queen, namely Queen Juliana in In the Netherlands, he even had to pay a fine and was imprisoned in a cell for preaching the Gospel outside the regional boundaries set by the Dutch government at that time. ${ }^{1}$

And a radical statement that is quite intriguing that the day of independence on August 17, 1945 is considered as the day of victory of Islam against Christianity. They have turned a blind eye to the history of this nation where young people from various tribes, both Tapanuli, Minahasa, Ambon, Kupang and many other Christian-based regions work together to build strength, fight for the independence of the Republic of Indonesia, and in the Oath Youth in 1928, there were no longer the terms Jong Batak, Jong Jawa, Jong Ambon, Jong Sunda or Jong Minahasa, which existed at that time as stated in the text of the "Youth Pledge", namely: We, the sons and daughters of Indonesia, claim to speak one language. Indonesia,We, the sons and daughters of Indonesia, claim to be one nation, the Indonesian nation,We, the sons and daughters of Indonesia, claim to be spilled one blood, spilled Indonesian blood. ${ }^{2}$ The author believes that the achievement of the independence of the Republic of Indonesia on August 17, 1945 was the result of the struggle of the Indonesian youth at that time, and also as a result of the struggle and sacrifice of various parties and all elements of this nation, including Christians, such as National Heroes. Patimura from Ambon, Dr. Sam Ratulangi from Minahasa, Young Marshal Yosafat Sudarso, Adi Sucipto from Java and Dr. TB. Simatupang from Tapanuli, and of course there are many more Christian figures who fought and sacrificed for that independence. ${ }^{3}$ On the other hand, this nation must not turn a blind eye to the actions of radical groups that disturb the security and stability of the nation, starting from the DI/ TII movement in 1959, the Tanjung Priuk and Borobudur incidents in 1982, the Surabaya Incident, Situbondo, Tasikmalaya, Rengas Dengklok and other events. other events that took place in 1996-1998. Likewise were the actions of certain sects and mass organizations that often "pestered" the nation. ${ }^{4}$

\section{Stream of Islam in Indonesia}

The Number of Muslims in Indonesia is far more than Muslims in other Islamic countries, both in Asia and the Middle East. ${ }^{5}$ Of the approximately 270 million population of Indonesia, it is estimated that the number of followers of Islam is up to 200 million. And the Muslim population of this size is divided into many Islamic sects or organizations, ranging from organizations recognized by the government to organizations that are not recognized, including the Ahmadiah Islamic sect whose name was sticking out, because it was considered illegal and heretical by Islamic schools. other, maybe one of the reasons is because they acknowledge another prophet besides Muhammad, namely the one named Gullam Ahmad. ${ }^{6}$

The number of schools of Islam in Indonesia can actually be understood, namely because of the existence of different interpretations or understandings, both about the Koran and other books, and the author feels that it is normal for such a large number of adherents. Because the same thing also happens with Christianity, which in terms of the number of its adherents in Indonesia is still far below Islam, but the number of organizations has reached hundreds of organizations. The flow of Islam in Indonesia can be classified in several ways, for example moderate Islam such as Muhammadiyah and fundamental Islam such as NU. ${ }^{7}$ Or based on their origins, namely Shia and Sunni. There are not too many Shias in Indonesia compared to Sunnis, but Islam, whose followers come

\footnotetext{
${ }^{1}$ Buku 63 Tahun Pinkster Beweging di Indonesia, Jakarta: Majelis Pusat GGP, 1987.

${ }^{2}$ Ghafur, Waryono Abdul. 2015. "Dakwah Islam dan Interaksi Interkultural”, dalam Kees de Jong dan Yusak Tridarmanto (ed.), Teologi dalam Silang Budaya: Menguak Makna Teologi Interkultural serta Perannya bagi Upaya Berolah Teologi di Tengah-tengah Pluralisme Masyarakat Indonesia, Yogyakarta: Taman Pustaka

3 Anis A. Soros, kebenaran Diungkapkan "pandangan Seorang Arab Kristen tentang Islam

4 Iwan Gayo, Buku Pintar, p. 109-110.

${ }^{5}$ Hermans, Hubert, dan Agnieszka Hermans-Konopka. 2010. Dialogical Self Theory: Positioning and Counter-Positioning in a Globalizing Society, Cambridge: Cambridge University Press,p/32

${ }^{6} \mathrm{Ibid}$

${ }^{7}$ Hasan,Noorhaidi.2012.“JalanLainMenujuDemokrasi”,dalamAinurRofiqal-Amin, Membongkar Proyek Khilafah al Hizbut Tahrir di Indonesia, Yogyakarta: LkiS,p.23
} 
from the Prophet Muhammad's family, still exists. It is estimated that the number of descendants of the prophet Muhammad who have reached the 43-45 generation worldwide at this time reaches 20,000,000. souls and $2,000,000$. souls reside in Indonesia, and they can be recognized easily because they wear the title Habib, especially for their ulama. ${ }^{1}$

Regulations Governing Religion in the Republic of Indonesia

The Indonesian nation and the Unitary State of the Republic of Indonesia are one of the nations or countries in the world that are very vulnerable to division or disintegration, because apart from being composed of many ethnic groups, they are separated by oceans and consisting of many islands, as well as many religions. ${ }^{2}$ That is why the Indonesian government has made a regulation regulating religious institutions in Indonesia.

Pancasila

Soekarno and Soeharto fundamentally had different political views, but in terms of Pancasila,they had the same view, this was evident when the second President of the Republic of Indonesia expressed his views and thoughts on Pancasila. ${ }^{3}$

Pancasila, which is formally contained in the 1945 Constitution, is rooted in noble values which for centuries have been part of Indonesian history and culture. In one of his remarks, President Soeharto once said: "We do not have the slightest doubt about the truth of Pancasila for the good, happiness and safety of our nation's life. Pancasila has undergone many tests, even today. It is true that there have been various attempts - some of them even using violence - to uproot Pancasila from the hearts of the Indonesian people, there have been various attempts to replace this country's philosophy with another one. This effort has always been thwarted by the Indonesian people themselves. This shows that Pancasila has truly become part of the life of this nation. Pancasila is the soul of all of us, the soul of all Indonesians. ${ }^{4}$ Pancasila has become a matter of life or death for our nation. ${ }^{5}$

Pancasila has also become the basis of this country, which is also the basis of all laws, laws and regulations that exist in this nation. It is well known by all, especially the Indonesian people, that the establishment of the Indonesian nation was based on five principles or five principles, which are called Pancasila (panca $=5$ and sila $=$ basic). ${ }^{6}$ And in the first Precepts it is very clear that the Indonesian nation and state are based on the one and only Godhead. The author's meaning is that every Indonesian citizen is obliged to be godly, or in other words, every Indonesian citizen is obliged to adhere to one of the religions of a number of religions that have been declared as legal religions in this Republic. So it includes Christianity or Christianity. Thus adhering to Christianity is legal according to Pancasila, because being religious or adhering to one of the officially declared religions is one of the obligations of the entire Indonesian nation.

\section{Constitution}

In the 1945 Constitution, namely in Chapter XI Article 29 it is said as Following:

Verse 1. The state is based on the One Godhead.

Verse 2. The state guarantees the freedom of every citizen to embrace his or her own religion and to worship according to that religion and belief

The contents of the 1945 Constitution Chapter XI Article 29 verse 2 above, according to the author's understanding, are, first, every Indonesian citizen is given the freedom to choose one of the official religions, adhere to it and also practice it in accordance with the teachings of his religion.?

Second, freedom to worship according to their respective religions and beliefs means that every member of a legitimate religion is given the freedom to practice their religious laws, regardless of their religion, including Christianity. This means that every Indonesian citizen who is a Christian is given the freedom to pray, to worship on Sundays or other days, without fear, even to testify, witnessing his belief in everyone, without coercion or intimidation, because according to Christians witnessing is part of worship. And according to the author, witnessing is legal as long as it does not force people or intimidate people to become Christians, because it is clear that this is guaranteed by the 1945 Constitution which is the highest law in this country, and is the highest legal basis upon which all regulations are based ${ }^{8}$ exists and is made in this country.

\footnotetext{
${ }^{1}$ Laksana, Albertus Bagus. 2014. Muslim and Catholic Pilgrimage Practices: Explorations Through Java, Burlington: Ashgate Publishing, Ltd,p. 12

${ }^{2}$ Eka Darmaputera, Pancasila Identitas dan Modernitas, Jakarta: BPK Gunung Mulia, 1997, p. 132

${ }^{3}$ Isma. 2016. "Mengisi Tafsir Pancasila", dalam Suara Muhammadiyah, Edisi No. 14, Th. ke-101, 16- 31 Juli 2016.

${ }^{4}$ Ibid

${ }^{5}$ Eka Darmaputera, Pancasila Identitas dan Modernitas, p. 132.

${ }^{6}$ Ibid

${ }^{7}$ H. Kaelan, Pendidikan Kewarganegaraan untuk perguruan Tinggi, Yogyakarta: Penerbit Paradigma, 2002 , p. 7

${ }^{8}$ Krieger, David J. 1991. The New Universalism: Foundation for a Global Theology, Meryknoll: Orbis Books,p.45
} 


\section{Ministry decision letter}

In connection with religious services and religious statements, the minister of religion and the minister of home affairs, as well as the Attorney General's Office, have regulated a lot about this, one of the decrees of the Minister of Religion and the Minister of Home Affairs, which is stated in the Joint Decree of the Minister of Religion and the Minister of Home Affairs No.01 / BER / MDN-MAG / 1969 Concerning the Implementation of Government Apparatus Duties in Ensuring Order and Smoothness in the Implementation of Development and Religious Worship by Adherents. Article 1. The regional head provides an opportunity for every effort to spread religion and worship by its adherents, as long as these activities do not conflict with the applicable law and do not interfere with security and public order (SKB 2 of the Minister is attached).

Decree of the Minister of Religion of the Republic of Indonesia No.70 of 1978. Concerning Guidelines for Religious Broadcasting. In this decision, the first point stated that: To maintain national stability and for the sake of religious harmony, the development and broadcasting of religion should be carried out in a spirit of harmony, tolerance, teposeliro, mutual respect, respect between religious communities according to the spirit of Pancasila. (The full decree is attached). ${ }^{1}$

\section{Other Decree Letters}

RI MPRS Decree No. XX / MPRS / 1966 said that a regulation "must be based and sourced firmly on the prevailing laws and regulations, which are of a higher level." But the authors sometimes see a confusion of regulations in this country, the Indonesian Ulema Council in Cianjur Regency issued a fatwa or a decision prohibiting the rebuilding of a church or church building either in the form of a new denomination, or a new church. which is a development of an existing church in Cianjur Regency, and when this is "violated", they will not hesitate to dissolve the church or fellowship, even the ongoing services, such as what happened in October to November 2006, there were several churches or posts. PI that must be dissolved and its worship activities stopped, on the grounds that the shop or house used for worship violates the planned use or designation of the building, but when the churches want to arrange a building permit for a church building, that step is suppressed in such a way either through the MUI fatwa or Perda, so it is somewhat impossible to un to be able to build a new church building or build a new church in a broad sense. This also happened with the GKI Hok Imtong church, which was started ten years ago in Cianjur Regency, because they did not have their own church building in early November 2006, or this church was dissolved by the masses. ${ }^{2}$ In fact, which regulation is higher in our country, Pancasila and its 1945 Constitution or MUI fatwas as well as local regulations and mass organizations that have sprung up at this time, including the Islamic Defenders Front (FPI), which is often confused by taking over the duties of the police. prosecutors, judicial duties and even local government duties. Because if we return to the MPRS Decree above, it is very clear that every regulation or decision, even law, must strictly refer to a higher provision, and in this country Pancasila and the 1945 Constitution are the highest provisions, meaning that all provisions and regulations must refer to Pancasila and the 1945 Constitution are not the opposite, that is, they are contradictory. Because it is clear that both Pancasila and the UUD'45 firmly guarantee freedom of religion and freedom to carry out religious law, in accordance with the provisions of their respective religions. ${ }^{3}$ The Indonesian Church Council (DGI) and the Supreme Council of Indonesian Bishops (MAWI) on January 14, 1979 made comments, because they felt there was a contradiction between the Decree of the Minister of Religion of the Republic of Indonesia No. 70 in 1977 and 1978 with a decree of 2 ministers, namely the Minister of Home Affairs and the Minister of Religion, No.1 of 1979 with dictum 2a Decree of the Minister of Religion No. 70 of 1978. quote SKB 2 of the Minister, article 1 paragraph 2, which reads: "This Joint Decree is not intended to limit efforts at the formation, development and broadcasting of religion in Indonesia" with article 4 which reads: The implementation of religious broadcasting is not allowed to be aimed at people or groups of people who have embraced / adhered to other religions, in a way ${ }^{4}$ :

a. Using persuasion with or without using the provision of goods, clothing, food or drink, medication, medicines and any other forms of giving so that people or groups of people who have embraced / adhered to another religion change and embrace / adhere to the religion it broadcasts.

b. b. Distributing pamphlets, magazines, bulletin, books, and other forms of printing goods to people or groups of people who have embraced / adhered to other religions.

c. Make door-to-door visits to people who have embraced other religions. ${ }^{5}$

Apart from DGI and MAWI, of course, we will all be able to see that there is a difference or contradiction

\footnotetext{
${ }^{1}$ Amandemen I, II, III, IV UUD 45 (Jakarta: Pustaka Agung Harapan, n.d.). p. 24.

Ibid

${ }^{3}$ Muslimin. 2017. "Paskah 2017, KAJ Usung Tema “Amalkan Pancasila: Makin Adil, Makin Beradab”, http://news.akurat.co/id-28701-readpaskah-2017-kaj-usung-tema- (diakses 17.05.2017, pukul 23.28 WIB).

Hendardi. 2017. "Setara Institute Beberkan Fakta Baru Aksi Penolakan Gereja Santa Clara", http://rmol.co/dpr/read/2017/03/27/285419/Setara-Institute-Beberkan-Fakta-Baru-Aksi- Penolakan- Gereja-Santa-Clara (diakses 02.04.2017, pukul 11.40 WIB).

${ }^{5}$ Weinata, Sairin, Himpunan Peraturan Di Bidang Keagamaan, Jakarta: BPK Gunung Mulia, 1996, p. 490-491
} 
between the decision of the Minister of Religion of the Republic of Indonesia above, which is a bit contradicting the SKB between the Minister of Religion and the Minister of Home Affairs, as quoted above.

\section{Religion, A Psychological-Historical Study}

Religious tolerance is a philosophy that regulates the relationship between one religion and another so that it remains harmonious and there is no disintegration. All religions in Indonesia, both "majority" and "minority" have agreed to uphold the noble values contained in Pancasila. In addition, the government has also provided relatively clear boundaries, there is freedom, but there are still boundaries and must respect each other. Above have described various regulations that should apply in this country, and are upheld by every religious adherent, regardless of majority or minority perspective; but for minorities they often feel that there are such constraints in exercising religious freedom, what is even more sad is the prohibition to testify to unbelievers, even though Pancasila and the 1945 Constitution give them freedom. Witnessing or witnessing is different from Christianization or Islamization or Hindunization. ${ }^{1}$ Testimony is a neutral term, but then it seems to have generalized or expanded its meaning, so that it is often seen as Christianization or Islamization. Testimony is an attitude, explanation, expression from someone who understands something, sees something, feels something, and he feels the need to tell it to others, not to influence or force others to follow that person's religion or belief.

In the concept of government, all Indonesian citizens have a religion, because it is based on the first precepts in Pancasila, namely: That the Unitary State of the Republic of Indonesia is based on the One Godhead ". Because one of the foundations of this country is almighty divinity, every Indonesian citizen must have a religion, which is why the author observes that the government often, whether consciously or not, has used religion to its citizens, so that in making a National Identity Card (KTP), it always includes the religion held by the KTP holder. The government redefined religion in 1957 along with the establishment of the Indonesian Ministry of Religion. The redefinition of "Religion" has disadvantaged the adherents of a large number of faiths in Indonesia21 because they are no longer allowed to include their belief in their National Identity Card, and instead "government" or officials write one religion on the KTP; Until now, in several places the term "beating flat" sometimes occurs, especially when filling in the religion column, without paying attention to the KTP form. The events and conditions that afflict some people like this can be interpreted that they are the same as people who are not yet religious, they have just arrived at the stage, are "made religious", or they are "subjected to religion" or "dressed in religion", and this is not the same with religion. That is why in Indonesia the term "abangan" Islam is known, namely those whose KTP is Islam, but in their daily life practice they still practice other beliefs, and this phenomenon by Dr. Baker and by Dr. Harun Hadiwiyono is referred to as a "stowaway", meaning that local beliefs or religions have become "stowaways" in official religions such as Islam and Christianity. Kaharingan, the regional religion of the Dayak people in Central Kalimantan, may be called the "official passengers" of Hinduism, as there seems to be an attempt by the "government" to incorporate the kaharingan into the Hindu religion. This is almost the same as the Confucian religion before it was recognized as an independent official religion. During the era of the Indonesian President Abdurrahman Wahid, Confucianism was used as a passenger in Buddhism and Hinduism.

The existence of the terms "fluidic" and "overlapping identity" above, has opened a very wide way for religious syncritism, so it is natural that even though their ID cards are Muslim or Christian, even Hindu, they still practice Animism, dynamism, regional religions, ethnic religions. and other beliefs.

This religious syncretism occurs not only among Sundanese or Javanese tribes, but this phenomenon occurs in almost every ethnic group in Indonesia. In this connection Islam and Christianity have been harmed, not benefited, but could it be because of the "generosity" of the Islamic and Christian scholars that they have allowed this incident to continue, without any real action to overcome it. In this regard, the government must immediately redefine the meaning of religion and belief to God Almighty, after that a pure return to Pancasila, in connection with freedom or freedom in the Almighty God, and if this happens, it means that the government will recognize the regional religion / tribal religion and beliefs that have long been "fixed. eskan "and have been a stowaway or official passenger on a religion that is considered legal or official.

Responding to mistakes, especially past mistakes, there must be a redefinition or redefinition of the terms "religion" and "being religious" so as not to harm certain groups. Apart from that, the current government must apologize to the people, on behalf of the past governments that have robbed them of their rights, especially the right to adhere to a belief or religion according to their own conscience; because many people have been deprived of their rights to adhere to one belief, a regional religion, and one of the official religions according to their own choice of heart, as stated in the 1945 Constitution Chapter XI Article 29 paragraph 2.

If the above happens, then to religious figures or ulama, do not be reluctant to give freedom to their respective people to make their choices, because the mandate of the 1945 Constitution teaches that there is no

\footnotetext{
${ }^{1}$ Weinata Sairin, Himpunan Peraturan di Bidang Keagamaan, 561-571
} 
coercion and deception in disseminating the teachings of their respective religions respectively. ${ }^{1}$

\section{INTERCULTURALITY OF INDONESIA RELIGION IN WEST JAVA CONTEXT}

Unity in Diversity, diverse but one existence. This National Motto accurately describes the deepest realities of Indonesia. It reflects such a determination to knit unity and togetherness of Indonesian society, which is perhaps the most heterogeneous society in the world. And the determination to unite reflects the existence of the same culture, behind a very striking plurality. At first glance the diversity and diversity of Indonesia is far more prominent than its unity, therefore the danger of disintegration is always a threat, both real and potential. ${ }^{2}$

Indonesia, is not only rich in culture, ethnicity and language, but Indonesia is also rich in religions, meaning that in Indonesia there are a number of religions and beliefs that are recognized and have legal positions according to the law in this country. Government steps some time ago, especially during the reign of President Soeharto, or during the New Order era, namely to make Pancasila as the only principle in society, nation and state. It is the right effort, although at first this effort had raised pros and cons among the community, and it is considered that there is a tendency towards intervention by the government against various social organizations (Ormas) ${ }^{3}$ and religious (religious) organizations in Indonesia, but actually through this effort, the government aims to build national unity and unity. That is why in every movement and effort every mass organization or religious institution must maintain and establish the unity and unity of the Indonesian nation, so that it does not collide with Pancasila, the 1945 Constitution, laws and other regulations, and also so that there is no disintegration of the Republic of Indonesia.

\section{Method of "Caina Herang Laukna Beunang"}

"Caina herang laukna benang"- the fish can but the water is clear. Is an expression which is the philosophy of the Sundanese ancestors in doing or doing something; the goal is achieved, the fish can - "laukna yarn" but the water is still clear - "caina herang" the water does not become cloudy, does not cause chaos or noise.

Within the Unitary State of the Republic of Indonesia there is an order that regulates the life of the nation, state and religion, so that the existing freedom is not misused, so that it can cause disharmony in relations with one another, including the relationship between religious communities, because all citizens of Indonesia are aware of the existence of "diversity. "Which is so heterogeneous.

In preaching and preaching the Gospel every cleric or religious figure or anyone may preach, explain, write down the strength or strength of their respective religion but without vilifying, scolding, comparing, then vilifying the teachings of other religions, and may not offend or hurt the hearts of religious people. other. ${ }^{4}$ So it is the responsibility of the ulama and religious leaders to explain clearly according to their respective abilities and expertise, while the people are given the freedom to make their choice, but there should not be intimidation or coercion, or "the lure of something". And then the religious leaders must with a big heart accept any reality, including if there are people who turn to other religions, on the basis of their own will.

The author feels sure that there is still a good, accurate, relevant way not to violate the existing order, namely in the context of witnessing in the Indonesian and Pancasila context. The author remembers very well what the Rev. Dr. Chris Marantika, D.D. That evangelism is an art. ${ }^{5}$ So high artistic ability is needed so that the goal is achieved or the laukna of the thread, but the water is still clear.

\section{Avoid Debate}

There needs to be a redefinition of the terms debate with dialogue, because these two terms are not the same. According to the author of the debate is a dialogue for each showing superiority, superiority, and intelligence or strength of each, that is why demonizing and attacking each other is common, such as the debate between Ahmed Deedat and Anis Shorros which was held in a conference hall in England, and watched or witnessed by both groups of devotees, and it often happened that both groups of both the audience and the arguing person became hot-hearted, their faces and ears turned red and went home in anger. And it is clear that for Indonesia's climate, which is very fragile, this should not be done. And in terms of results, for example the opponent in the debate turns to follow his religion or belief, very rarely, and what often is the opposite, namely hostility, and this is the author's experience, for example in 1983 in Padalarang Bandung, on the sidewalk by the side of the road, the author argued with someone. Haji, who works as a seller of books for Muslim reading, at that time the author

\footnotetext{
Nadlir, Moh. 2017. "Percepat Pembubaran HTI, Pemerintah Pikirkan Opsi Terbitkan Perppu", http://nasional.kompas.com/read/2017/05/16/21192561/percepat.pembubaran.hti. pemerintah.pikirkan.opsi.terbitkan.perppu (diakses 20.05.2017, pukul 11.30 WIB).

240 Eka Darmaputera,Pancasila Identitas dan Modernitas, p.22

${ }^{3}$ Wijsen, Frans 2015. Christianity and Other Cultures: Introduction to Mission Studies, Lit Verlag. Wirutomo, Paulus, dkk. 2012. Sistem Sosial Indonesia, Jakarta: Universitas Indonesia Press.

${ }^{4}$ Van den End, Sejarah Peerjumpaan Gereja dan Islam, Jakarta: BPK Gunung Mulia, 1990, p. 67-68

${ }^{5}$ Tanja, Victor I. 1998. Pluralisme Agama dan Problem Sosial: Diskursus Teologi tentang Isu-isu Kontemporer, Jakarta: Pustaka Cidesindo,P.5
} 
was briefly insulted by the Haji. And when we trace the history of Christian- Islamic encounters, with various debates, starting from Patriarch Timotius I a Catholic living (circa 728-823) with Caliph Al-Mahdi and sultan Harun Al- Rashid (during his reign around 775-809 AD). Antara Jahannes Damascenus (665- 750), a figure of the Eastern Orthodox church. This was done by Basillius I and Niketas of Bynzantium (867-1056), as well as Bartholomew of Edessa (1100), Niketas Akominatos, an archbishop of the former emperor (- 1225), and also Johannes Kantakuzenos (1360). There are many other figures who are very concerned about focusing their services on the Islamic world, but the author reads that the results are not as expected, even though they may not be without results.

Dialogue, in simple terms can be interpreted as an effort made by two different groups of people or two people of different religions, then they each agree to exchange ideas, with the aim of each wanting to know the sincere beliefs of their friends, with questions - a genuine question, and not to discredit or offend. In fact, according to the authors, this kind of dialogue is still quite relevant in a country based on Pancasila, as long as each sincerely agrees to respect each other.

\section{Avoid arrogance}

The arrogance that is meant here is, an act of violence, intimidation, coercion, provoking the masses for various negative things, assault, namely in the sense of attacking the beliefs of others, vilifying and scoffing at the beliefs of others in public, and through the mass media, as well as various other acts of violence that can harm other parties.

Religious arrogance is an attitude that arises due to several factors, for example feeling as the majority, feeling as having power, feeling as self-righteous, because of jealousy and hatred and wanting to be in power and to become rulers as well as several other factors,

All religious people in Indonesia should not commit this bad act against followers of other religions, even though they may be in majority areas.In Christianity, Christ Jesus has provided a perfect example when He lived in His incarnation in this world, as well as his teachings, namely that we love each other, including loving those who do not have the same religion or belief.

In a country based on Pancasila and the 1945 Constitution, arrogance is not appropriate, but must be eliminated completely, because it is clear that it violates Human Rights, and is contrary to the culture inherited from the nation's ancestors, namely polite, friendly, ethical character, compassion, tepo seliro. And this is also contrary to the culture of the Indonesian people who are accustomed to living in diversity and diversity.

\section{Avoid Overlapping Methods}

Psychologically, basically humans are creatures who like to imitate, especially for something good and profitable. On the other hand, humans do not like to be imitated, especially with regard to things that are quite essential, for example the recipe for food / cooking of a restaurant, a method that is quite accurate and proven to be successful in doing business, a product of a company, which is why we know the term patent, which is legality. which states the ownership or rights of a person or a company, and if it turns out that at any time it is found that the patent rights were copied by the company or someone, he will immediately report the matter to the authorities, and the imitator can be sued.

Muslims do not like it when people of other religions imitate them, especially imitate their way of worship, their way of dressing, their way of preaching, and also other ways. The author remembers that in the late eighties to the nineties, when a Christian institution published the Gospel of Luke with a cover or title similar to Arabic calligraphy, many Muslims were offended, even some of their mass media said that Indonesian Christians were manipulating. , and various other comments that are not pleasant to hear or read. Dr. John Culver, in the MuslimChristian Encounter class ${ }^{1}$, once told that a Christian institution published the Book of Proverbs, with the name "Wisdom of the Prophet Sulayman" which was criticized by Muslims, they urged the institution to immediately withdraw all books that have been circulating, especially those that are still in existence. in bookstores. And in terms of clothing or clothing, Muslims are also not happy when people of other religions imitate their dress, because for Muslims that is their identity. For Christians they do not have any characteristic clothing, except for a certain sect, but they do not represent Christians in general. But if there is something that is characteristic of a religion, and then followers of other religions imitate it, especially in relation to preaching and preaching the Gospel, that should also be unethical. So don't use the "imitate/overlapping" method.

\section{Making Sincere Friendships}

In many minority countries who live under the pressure of the majority, live in fear and bitterness, but they can do nothing because they are afraid, and are helpless especially in relation to religion and worship; On the other hand, the majority live in arrogance, and they suppress the weak, so that their relationship can be likened to a fire

\footnotetext{
${ }^{1}$ Van Bruinessen, Martin (ed.). 2014. Conservative Turn: Islam Indonesia dalam Ancaman Fundamentalisme, Bandung: Mizan,p.23
} 
in the husks, outwardly invisible, but inside there is a fiery red fire. If this situation is left without resolution and the government's efforts should one day disrupt and threaten national stability.

This situation is not expected by the government, which is why many efforts have been made by the government to create harmony between religious communities.

"Forge genuine friendships with them." And this attitude is a reflection of the teaching of the Lord Jesus: Sincere like a dove and clever like a snake (Matt. 10:16).

If there has been a refusal in service so far some people say that it is because $60 \%$ is the factor of the person concerned, and not the factor of society who refuses. So if $60 \%$ is the factor of servants of God or Christians themselves, then it means that the rejection or acceptance of someone's service is largely dependent on the Christian or the servant of God concerned.

\section{CONCLUSIONS AND CONTRIBUTION}

There are many roads leading to Rome, this is an expression that the author feels, but actually not only the author, but surely there are still many other believers who have this kind of belief, in connection with da'wah and PI in this country. At first glance, it seems that every gap for da'wah and PI in this country has been closed tightly, so that it seems as if there is no way or opportunity to carry out the Great Commission. But the author believes that His power is still valid, the promise of His participation is still valid, His miracles are stil, so therefore his orders with respect to the Great Commission are still valid.

Believers in Indonesia can still implement PI in this country, without fear of violating existing government provisions, and without fear of being called less Pancasila or not having religious tolerance, or other terms similar to that, because the author believes that with an attitude of tolerance, or mutual respect among adherents of different religions, and also in a country based on Pancasila, we can still implement PI as discussed in the section above.

In addition to some of the methods above that are often forgotten by believers and evangelists, in this section the author also wants to give some suggestions, first: Implementing PI in Indonesia must not be radical or frontal nor can it be a kind of revolutionary movement, both in terms of ways. nor in expecting results. Second, enter through subtle, but sincere, slow but constant means, until you get recognition naturally from the surrounding community, that in the area there are believers or a group of believers, whose existence is clear and transparent, so as not to raise suspicions either. from the local community as well as from the government. Third, adapt as best as possible in the community and also in any existing community activities, especially if the PI is held in rural areas. Fourth. Be a good role model for society in all aspects of life, both in terms of morals, kindness, family, economic conditions, as well as in relation to society, adherents of other religions, and government, for example in relations with taxpayers, in mutual cooperation and so on., so that there is no gap for those who do not believe to accuse us, but instead they see a very different quality of life, very high quality. It is our duty, the believers in this country, to do what is our duty and responsibility, our part. While God's responsibility, let us return it to Him. Our obligation is to do what we can do. And for the end result we leave it to God who has the work, because in fact we are only His partners exspecially in West Java.

\section{REFERENCES}

Adeney, Bernard T. 2000. Etika Sosial Lintas Budaya, Yogyakarta: Kanisius. Adeney-Risakotta, Bernard. 1997.

"Allah yang Bhineka Tunggal Ika", Duta Wacana:

Majalah Ilmiah Universitas Kristen Duta Wacana, I/2, Oktober 1997.

2015. "Imajinari Sosial Indonesia dan Barat", dalam Bernard Adeney- Risakotta (ed.),

Mengelola Keragaman di Indonesia: Agama dan Isu-isu Globalisasi, Kekerasan, Gender dan Bencana di Indonesia, Yogyakarta: ICRS-Yogyakarta dan Mizan.

Adian, Donny Gahral. 2017. "Radikalisme dan Pancasila”, Kompas, 14 Januari 2017.

Darmaputera, Eka. 1992. Pancasila, Identitas dan Modernitas: Tinjauan Etis dan Budaya, Jakarta : BPK Gunung Mulia.

1996. "Tugas Panggilan Bersama Agama-Agama di Indonesia: Suatu Refleksi Kristiani”, dalam T.B. Simatupang, Peran Agama-Agama dan Kepercayaan Terhadap Tuhan Yang Maha Esa dalam Negara Pancasilayang Membangun, Jakarta: BPK Gunung Mulia.

1997. "Pergumulan dan Peran Gereja dalam Masyarakat dan Negara Pancasila", dalam

J.M. Pattiasina dan Weinata Sairin (eds.), Gerakan Oikoumene Tegar Mekar di Bumi Pancasila: Buku Peringatan 40 Tahun PGI, Jakarta: BPK Gunung Mulia.

De Jong, Kees. 2008. "Keanekaragaman Bentuk Kekristenan Global”, Gema Teologi, Vol. 32, No. 1, April 2008. 2010. "Pekabaran Injil dalam Konteks Masyarakat Multikultural Pluralistik", dalam Hendri

Wijayatsih (ed.), Memahami Kebenaran Yang Lain sebagai Upaya Pembaharuan Hidup Bersama, Yogyakarta: Mission 21, UKDW, TPK.

De Wit, Hans. 2004. "Intercultural Bible Reading and Hermeneutics", dalam Hans de Wit (ed.), Through the Eyes 
of Another: Intercultural Reading of the Bible, Amsterdam: Institute of Mennonite Studies dan Vrije Universiteit.

Dewan Karya Pastoral Keuskupan Agung Semarang. 2016. Nota Pastoral Arah Dasar KAS 2016- 2020: Membangun Gereja yang Inklusif, Inovatif dan Transformatif demi Terwujudnya Peradaban Kasih di Indonesia, Semarang: Dewan Karya Pastoral Keuskupan Agung Semarang.

Darmaputra, Eka,1997. Pancasila Identitas dan Modernitas, Jakarta: BPK Gunung Mulia,

End, Van den, 1996. Sejarah Perjumpaan Gereja dan Islam, Jakarta

Ghafur, Waryono Abdul. 2015. "Dakwah Islam dan Interaksi Interkultural", dalam Kees de Jong dan Yusak Tridarmanto (ed.), Teologi dalam Silang Budaya: Menguak Makna Teologi Interkultural serta Perannya bagi Upaya Berolah Teologi di Tengah-tengah Pluralisme Masyarakat Indonesia, Yogyakarta: Taman Pustaka Kristen dan Fakultas Teologi UKDW.

Gayo, Iwan, 2003.Buku Pintar, Jakarta: Penerbit Upaya Warga Negara

Hadiwijono, Harun Religi Suku Murba di Indonesia, Jakarta: BPK. Gunung

Mulia, t.t. HAMKA,1978. Pelajaran Agama Islam, Jakarta: Penerbit Bulan Bintang.

H. Kaelan, 2002.Pendidikan Kewarganegaraan untuk Perguruan Tinggi, Yogyakarta; Paradigma.

Kapita Selekta, 1979.Sidoarjo: Yayasan Kesejahteraan Rakyat "Padepokan Samunggaling."

Morey, Robert, 1992.Islamic Invaion, USA: Overseas Ministry, Moshay, G.J.O.1994. Who is this Allah,

USA: Garden Grove.

Nurwahid Hidayat, 2002.Ensiklopedi Islam untuk Pelajar Indonesia, ( Artikel).

Pejalanan Bung Karno, 1978.Bogor: Yayasan Multatuli.

Sairin, Weinata,1996. Himpunan Peraturan Di Bidang Keagamaan, Jakarta: BPK Gunung Mulia.

Shorrosh, Anis A.1988. Kebenaran Diungkapkan "Pandangan Seorang Arab Kristen Tentang Islam”, Jakarta: Yayasan Pusat Penginjilan Alkitabiah.

Sukarna, 2004.Diktat Kuliah Agama Suku, Bogor: STT Kadesi.

2004.Diktat Sosiologi, Manusia dan Kebudayaan di Indonesia, Bogor: STT Kadesi,

Hasan, Noorhaidi. 2012. "Jalan Lain Menuju Demokrasi”, dalamAinur Rofiq al-Amin, Membongkar Proyek Khilafah al Hizbut Tahrir di Indonesia, Yogyakarta: LKiS.

Hermans, Hubert, dan Agnieszka Hermans-Konopka. 2010. Dialogical Self Theory: Positioning and CounterPositioning in a Globalizing Society, Cambridge: Cambridge University Press.

Isma. 2016. "Mengisi Tafsir Pancasila", dalam Suara Muhammadiyah, Edisi No. 14, Th. ke-101, 16- 31 Juli 2016.

Krieger, David J. 1991. The New Universalism: Foundation for a Global Theology, Meryknoll: Orbis Books.

Küster, Volker. 2001. The Many Faces of Jesus Christ: Intercultural Christology, terj.

John Bowden, London: SCM Press.

Laksana, Albertus Bagus. 2014. Muslim and Catholic Pilgrimage Practices: Explorations Through Java, Burlington: Ashgate Publishing, Ltd.

Latif, Yudi. 2011. Negara Paripurna: Historisitas, Rasionalitas, dan Aktualitas Pancasila, Jakarta: Gramedia. 2008. Menyemai Karakter Bangsa: Budaya Kebangkitan Berbasis Kesastraan, Jakarta: Kompas Media Nusantara.

Maarif, Ahmad Syafii. 2010. "Politik Identitas dan Masa Depan Pluralisme Indonesia", dalam Ihsan Ali-Fauzi dan Samsu Rizal Panggabean (eds.), Politik Identitas dan Masa Depan Pluralisme Kita, Jakarta: PUSAD, Yayasan Wakaf Paramadina, NPN, dan MPRK-UGM.

Moyaert, Marianne. 2011. Fragile Identities: Towards a Theology of Interreligious Hospitality, Amsterdam-New York: Rodopi.

Muhibat, Shafiah F.(ed.). 2014. Untuk Indonesia 2014-2019: Agenda Sosial-Politikdan Keamanan, Jakarta: CSIS.

Mujiburrahman, dkk. 2011. Badingsanak Banjar-Dayak: Identitas Agama dan Ekonomi Etnisitas di Kalimantan Selatan, Yogyakarta: CRCS UGM.

Persekutuan Gereja-Gereja di Indonesia. 2015. Dokumen Keesaan Gereja Persekutuan Gereja- Gereja di Indonesia (DKG-PGI) 2014-2019, Jakarta: BPK Gunung Mulia.

Prasetyo, Djoko. "Konvivenz dan Theologia Misi Interkultural Menurut Theo Sundermaeier”, Gema Teologi, Vol. 32, No. 1, April 2008.

Prayogo, Y. 2015. "Menjadi Komunitas dan Gerakan Alternatif: Dialog dengan Mgr. Suharyo”,Hidup, No. 40, Th. ke-69, 4 Oktober 2015.

Scheuerer, Frans Xaver. 2001. Interculturality: A Challenge for the Mission of the Church, Bangalore: Asian Trading Corporation.

Schreiter, Robert J. 1998. The New Catholicity: Theology between the Global and the Local, New York: Orbis Books.

Schumann, Olaf. 2014. “Misiologi atau Teologi Interkultural?”, Sola Experientia, Vol. 2, No. 2, Oktober 2014. 
Senior, Donald, dan Carroll Stuhlmueller. 1983. The Biblical Foundation for Mission, Maryknoll- New York: Orbis Books.

Setio, Robert. 2015. "Menimbang Posisi Teologi Interkultural", dalam Kees de Jong dan Yusak Tridarmanto (eds.), Teologi dalam Silang Budaya: Menguak Makna Teologi Interkultural serta Perannya bagi Upaya Berolah Teologi di Tengah-tengah Pluralisme Masyarakat Indonesia, Yogyakarta: TPK dan Fakultas Teologi UKDW.

"Ambiguitas, Interkulturalitas, dan Hibriditas Relasional dalam Relasi antara Israel dan Bangsa-bangsa Lain”, Diskursus, Vol. 13/1, April 2014.

Simon, John C. 2015. "Sejarah Kerohanian Indonesia sebagai Penegasan 'Kultur Hibrida': Dialog Kritis dengan Jacob Sumardjo", dalam Kees de Jong dan Yusak Tridarmanto (eds.), Teologi dalam Silang Budaya: Menguak Makna Teologi Interkultural serta Perannya bagi Upaya Berolah Teologi di Tengah-tengah Pluralisme Masyarakat Indonesia, Yogyakarta: TPK dan Fakultas Teologi UKDW.

Singgih, Emanuel Gerrit. 2004. Berteologi dalam Konteks: Pemikiran-pemikiran Mengenai Kontekstualisasi Teologi di Indonesia, Yogyakarta dan Jakarta: Kanisius dan BPKGunung Mulia.

Sumardjo, Jakob. 2002. Arkeologi Budaya Indonesia: Pelacakan Hermeneutis-Historis terhadap Artefak-Artefak Kebudayaan Indonesia, Yogyakarta: Qalam.

Tanja, Victor I. 1998. Pluralisme Agama dan Problem Sosial: Diskursus Teologi tentang Isu-isu Kontemporer, Jakarta: Pustaka Cidesindo.

Titaley, John A. 2016. "Mengembangkan Sumber Daya Gereja untuk Meningkatkan Pelayanan dan Kesaksian yang Mendatangkan Damai Sejahtera di Tengah dan Bersama Masyarakat", dalam John C. Simon (ed.), Melangkah pada Jalan Damai Sejahtera, Jakarta: BPK Gunung Mulia.

Van Bruinessen, Martin (ed.). 2014. Conservative Turn: Islam Indonesia dalam Ancaman Fundamentalisme, Bandung: Mizan.

\section{(ed.).}

2013. Contemporary

Developments

in Indonesian Islam: Explaining the "Conservative Turn", Singapore: ISEAS.

Wijsen, Frans 2015. Christianity and Other Cultures: Introduction to Mission Studies, Lit Verlag. Wirutomo, Paulus, dkk. 2012. Sistem Sosial Indonesia, Jakarta: Universitas Indonesia Press.

Website

Hendardi. 2017. "Setara Institute Beberkan Fakta Baru Aksi Penolakan Gereja Santa Clara", http://rmol.co/dpr/read/2017/03/27/285419/Setara-Institute-Beberkan-Fakta-Baru-Aksi- Penolakan-GerejaSanta-Clara (diakses 02.04.2017, pukul 11.40 WIB).

Muslimin. 2017. "Paskah 2017, KAJ Usung Tema "Amalkan Pancasila: Makin Adil, Makin Beradab", http://news.akurat.co/id-28701-read-paskah-2017-kaj-usung-tema-(diakses 17.05.2017,pukul 23.28 WIB).

Nadlir, Moh. 2017. "Percepat Pembubaran HTI, Pemerintah Pikirkan Opsi Terbitkan Perppu", http://nasional.kompas.com/read/2017/05/16/21192561/percepat.pembubaran.hti. pemerintah.pikirkan.opsi.terbitkan.perppu (diakses 20.05.2017, pukul 11.30 WIB).

Buku 63 Tahun Pinkster Beweging di Indonesia, Jakarta: Majelis Pusat GGP, 1987. 